\title{
Pengamatan Badai Cuaca Di Selat Makassar Untuk Mendukung Aktivitas Peluncuran Satelit
}

\author{
Wayan Suparta \\ Program Studi Informatika, Universitas Pembangunan Jaya \\ J1. Cendrawasih Raya Blok B7/P Bintaro Jaya, Ciputat, Tangerang Selatan 15413, Indonesia \\ wayan.suparta@upj.ac.id
}

\begin{abstract}
Thunderstrorms is one of the most important parameters that need to be considered in the scenario of launch a rocket or satellite launch into its orbit. This paper aims to measure the occurrence of thunderstrorms adjacent to the Makassar Strait area as a first step to building a thunderstrorm model in the context of satellite launches. Daily surface meteorological data such as pressure, temperature, relative humidity, cloud cover, water vapor, wind speed and wind direction have been analyzed. The analysis also considers the dry season and the rainy season near the launch target area. The results showed that stormy activity in May and October was detected $46 \%$ higher than in other months. The initial investigation found that thunderstrorms activity in this area was more affected by the relative humidity and water vapor, especially in the transition season (intermonsoon). While the months predicted to be safe for rocket launches are June, July and August.
\end{abstract}

Keywords : Meteorology, Thunderstorms, Monsoon, Makassar Strait, Satellite Launch

\begin{abstract}
Abstrak : Ribut cuaca adalah salah satu parameter terpenting yang perlu diperhatikan dalam skenario peluncuran roket atau peluncuran satelit menuju orbitnya. Tulisan ini bertujuan untuk mengukur terjadinya ribut badai berdekatan daerah Selat Makassar sebagai langkah awal untuk membangun model badai cuaca dalam rangka peluncuran satelit. Data meteorologi permukaan harian seperti tekanan, suhu, kelembaban relatif, tutupan awan, uap air, kecepatan angin dan arahnya telah dianalisis. Analisis juga mempertimbangkan musim kemarau dan musim hujan di dekat kawasan target peluncuran. Hasil penelitian menunjukkan bahwa aktivitas ribut badai pada bulan Mei dan Oktober terdeteksi 46\% lebih tinggi daripada bulan-bulan lainnya. Investigasi awal ditemukan bahwa aktivitas ribut badai di daerah ini lebih dipengaruhi oleh kelembaban relatif dan uap air, khususnya di musim peralihan (Monsun). Sementara bulan-bulan yang diprediksi aman untuk peluncuran roket adalah Juni, Juli, dan Agustus.

Kata Kunci : Meteorologi, Badai, Monsun, Selat Makassar, Peluncuran Satelit
\end{abstract}

\section{PENDAHULUAN}

Ribut badai adalah berbahaya dan sangat mempengaruhi aktivitas ruang angkasa seperti saat peluncuran satelit atau penerbangan komersial. Untuk itu, roket peluncur atau badan satelit bahkan telah dilengkapi dengan bahan anti badai supaya muatan sensitifnya dapat menarik badai (sangkar Faraday). Pesawat komersial yang terbang di bawah 35,000 kaki (titik ideal di ketinggian 30,000 - 42,000 kaki) memang sangat nyaman dengan kehadiran teknologi sangkar Faraday ini. Namun roket yang membawa satelit dan meluncur hingga ketinggian 123,520 kaki tidak akan aman dari serangan cuaca angkasa yang ganas. Untuk alasan ini, aktivitas yang terkait dengan ruang angkasa sering tertunda dari situasi yang ideal. Ribut badai sering terjadi melalui awan kumulonimbus dengan terpicunya badai petir. Tergantung pada lokasi geografi, badai biasanya disertai dengan angin kencang, hujan lebat dan kadang-kadang hujan es, salju, atau sebaliknya dan badai ini dapat terjadi tanpa hujan.

Musim dengan hari tenang (cuaca normal) sangat penting untuk menentukan perubahan kejadian ribut badai dan jika ini dapat diidentifikasi dengan akurat maka peluncuran satelit melalui roket dapat tinggal landas dengan aman dari landasan peluncuran (keypad) ke sistem luar angkasa. Upaya meningkatkan kehandalan akurasi peramalan terhadap bahaya badai yang tak terduga ini adalah sangat penting. Awan konvektif dapat terbentuk kapan saja di tropopause karena perbedaan dalam 
tekanan, pengangkatan termal, atau pola aliran angin. Dalam studi aktivitas sistem konvektif, Suparta et al. (2015) telah menemukan bahwa aktivitas Mesoscale Convective System (MCS) meningkat pada bulan Desember, Januari, dan Februari (DJF) di Tawau, Sabah. Pielke (2001) telah mempelajari konvergensi mesoscale sebagai lingkungan prakondisi untuk terbentuknya ribut badai dan membuktikan bahwa awan kumulonimbus menunjukkan pengaruhnya yang signifikan.

Dalam studi ini, kajian lebih difokuskan untuk menganalisa terjadinya badai cuaca untuk kemudian dapat digunakan sebagai bahan mitigasi keangkasaan seperti pemodelan saat berangkat atau lepas landas alat angkasa dari peluncuran roket. Kawasan yang menjadi objek sebenarnya adalah Selat Makassar karena titik peluncur roket (keypad) direncanakan akan dibangun di Tawau, Sabah, Malaysia (Kalimantan) atau berdekatan dengan Laut Sulawesi. Kawasan udara di atas selat ini adalah salah satu poin yang menguntungkan untuk mempelajari efek potensial badai pada kegiatan kedirgantaraan. Angin musim kemarau dicirikan dengan cuaca panas yang kuat, umumnya angin membawa uap air yang signifikan ke Asia Tenggara dan terutamanya akan membawa aktivitas sistem konvektif ke Selat Makassar. Jadi, wilayah atmosfer di kemaritiman Kalimantan-Sulawesi menjadi isu sentral (terdampak) jika space laucher akan dibangun di Sabah, Malaysia. Karenanya kajian ini berupaya mengkarakterisasi parameter meteorologi yang berkontribusi besar dalam pembentukan awan badai yang kemudian akan digunakan sebagai masukan untuk pengembangan model badai saat peluncuran roket.

\section{METODE PENELITIAN}

\section{Set Data dan Lokasi}

Daerah Tawau dipilih untuk studi ini karena diramalkan menerima hembusan angin kuat dari Laut Sulu dan Laut
Sulawesi dan berpotensi menghasilkan badai tertinggi setiap tahunnya. Tawau terletak di koordinat geografis $4^{\circ} 19^{\prime} \mathrm{LU}$ dan $118^{\circ} 07^{\prime}$ BT di atas permukaan laut rata-rata (MSL) $17,5 \mathrm{~m}$ atau berbatasan dengan Pulau Sebatik dan Nunukan (Indonesia) dan dipilih oleh Pemerintah Malaysia sebagai program keypad masa depan. Untuk menyelidiki terjadinya badai di daerah Tawau, beberapa parameter yang relevan akan diidentifikasi dan dianalisa. Data meteorologi permukaan di kawasan ini dikumpulkan dari sumber yang berbeda. Data tutupan awan (Okta), badai petir, kecepatan angin (knot) dan arah angin (derajat) dibeli dari Departemen Meteorologi Malaysia (MetMalaysia). Tekanan permukaan (mbar), suhu $\left({ }^{\circ} \mathrm{C}\right)$, dan kelembaban relatif (persen) diambil dari situs web www.wunderground.com dengan durasi per jam. Data uap air dalam bentuk uap air terpresipitasi (atau Precipitable Water Vapor - PWV) dengan durasi per hari didapat dari Universitas Wyoming website. Data yang diamati ini diambil dari 2011 hingga 2013. Catatan bahwa data ribut badai harian yang dibeli dari MetMalaysia dicatat secara manual, yang berarti bahwa jika terjadi badai nilainya diberi 1 atau ya, jika tidak ada badai, nilainya diberi 0 . Jadi data mentah ribut badai dalam bentuk seri waktu tidak tersedia dari MetMalaysia atau sumber manapun dari website. Karenanya dalam kajian ini, data badai petir tersebut digantikan dengan PWV yang juga dapat diturunkan melalui pengukuran GPS (Suparta, 2014).

\section{Pengolahan Data}

Semua data meteorologi permukaan, kecuali data ribut badai, diteliti melalui penilaian kualitas sebelum diplot dalam bentuk seri waktu. Data meteorologi seperti kecepatan angin dan arah angin diproses dengan menggunakan perangkat lunak WRPLOT untuk menunjukkan distribusi frekuensinya. WRPLOT adalah program freeware yang disediakan untuk visual wind rose, analisis frekuensi, dan plot untuk 
beberapa format data meteorologi (WRPLOT View ${ }^{\mathrm{TM}}$, 2011). Data permukaan meteorologi lainnya diproses dengan menggunakan perangkat lunak MATLAB. Kemudian, data tersebut dibandingkan dan dianalisis dengan kejadian ribut badai untuk daerah sekitaran Tawau.

\section{HASIL PENELITIAN DAN DISKUSI}

\section{Karakterisasi Angin Di Daerah Tawau}

Gambar 1 menunjukkan plot distribusi kecepatan angin dan arah angin di Tawau untuk tahun 2011, 2012, dan 2013. Arah utama kecepatan angin adalah dari Utara-Barat Laut (UBL) di mana Laut Sulu dan Gunung Kinabalu mempengaruhi daerah Tawau. Pada arah ini, kecepatan angin sering terjadi di kelas dua (1-4 knot). Arah angin lainnya adalah dari Selatan, di mana kecepatan angin dikategorikan di kelas tiga (4-7 knot).

Melihat arah aliran, angin yang berasal dari Laut Cina Selatan dan Pasifik Utara terjadi selama musim timur laut sementara angin barat daya berasal dari daerah kering Australia. Maret dan Oktober membentuk transisi antara dua musim peralihan (monsun). Angin dari arah UBL sering terjadi dan kadang-kadang di kelas tiga karena munculnya musim dingin di setiap tahun. Namun, pola angin di arah barat laut berbeda di setiap tahunnya karena perubahan musiman di Asia yang sedikit mempengaruhi wilayah ini (Loo et al., 2015).

Angin dari arah Selatan setiap bulan pada tahun 2013 menunjukkan kecepatannya di kelas tiga (berbahaya) daripada angin dari arah utara. Dengan kata lain, selama musim dingin, kecepatan angin lebih sering di kelas tiga dibandingkan selama musim panas (lihat selengkapnya di Gambar 2).

Selama musim panas (akhir Mei 2011 hingga September 2013), kecepatan angin sering terjadi dari arah selatan (dari Selat Makassar) dan umumnya berada di kelas tiga. Dari data yang dianalisa (Gambar 1), kecepatan angin dari arah Selatan dialami setiap tahun dan angin ini berbahaya bagi aktivitas penerbangan. Oleh karena itu, untuk kegiatan penerbangan komersial disarankan tinggal landas dari arah utara.

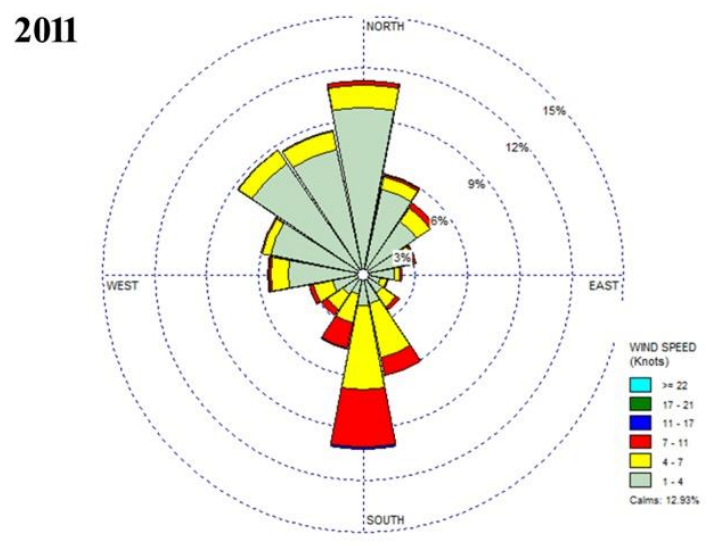

2012

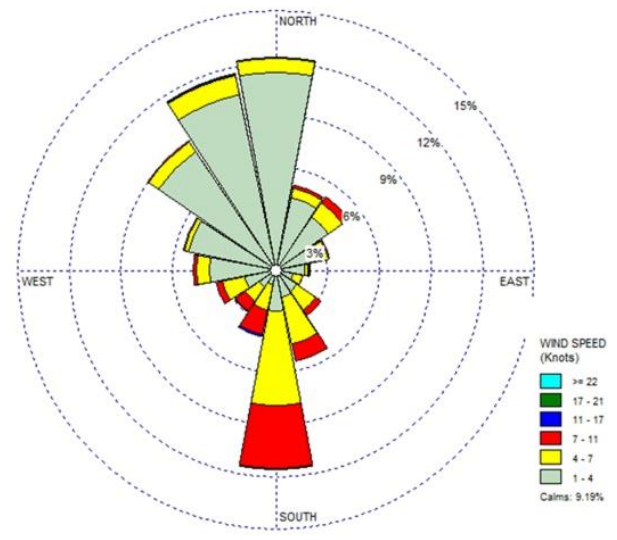

2013

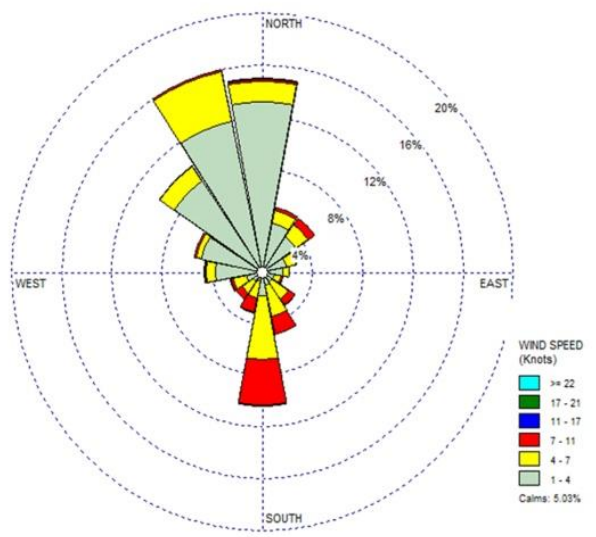

Gambar 1. Variasi rose angin di wilayah Tawau pada tahun 2011, 2012, dan 2013

Saran ini valid karena asumsi yang sama didukung oleh Islam (2011) bahwa selama musim panas, sebagian besar kecepatan angin rata-rata per bulan adalah 
antara $2,5 \mathrm{~m} / \mathrm{s}$ dan $4 \mathrm{~m} / \mathrm{s}$, namun beberapa dapat lebih dari $4 \mathrm{~m} / \mathrm{s}$ dan sedikit di bawah $2,5 \mathrm{~m} / \mathrm{s}$.

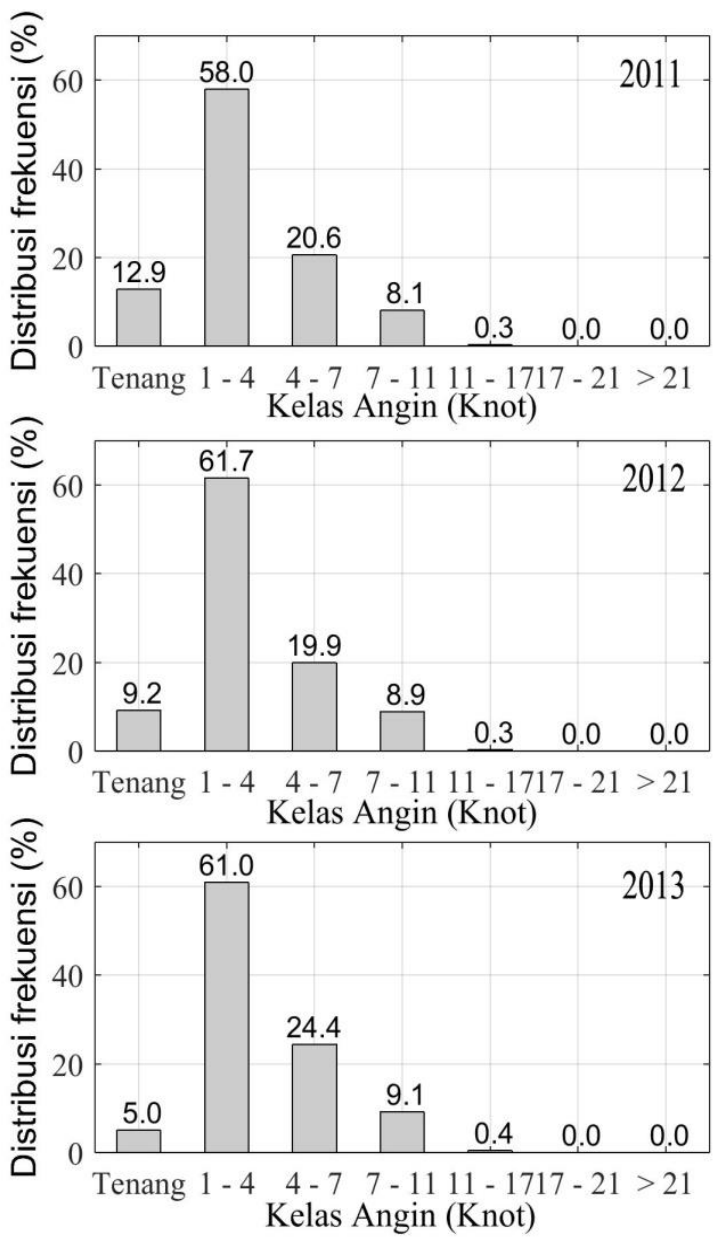

Gambar 2. Distribusi frekuensinya di wilayah Tawau pada tahun 2011, 2012, dan 2013

\section{Tutupan Awan}

Gambar 3(a) menunjukkan tutupan awan atau cloud cover (Okta) di atas kawasan Tawau. Seperti yang terlihat pada Gambar 3(a), rata-rata maksimum bulanan sebelum mulai musim peralihan pada bulan Maret, tutupan awan lebih dari 7 Okta yang menunjukkan bahwa kecepatan angin selama bulan itu adalah rendah (kelas 1 dan 2) di daerah utara dan tinggi (kelas 3) di bagian selatan. Tutupan awan dengan lebih dari 7 Okta menunjukkan bahwa langit benar-benar berawan (mendung), dan pada tahap ini, nilai tekanan akan tinggi, suhu dan kelembaban relatif akan menurun. Temuan di mana tutupan awan meningkat akibat peningkatan aktivitas kecepatan angin mirip dengan yang diperoleh Morris et al. (2001). Secara umum, variasi tutupan awan dapat dikatakan sedang hingga rendah dari April hingga Desember, dan oleh karena itu, daerah ini cocok untuk kegiatan kedirgantaraan.

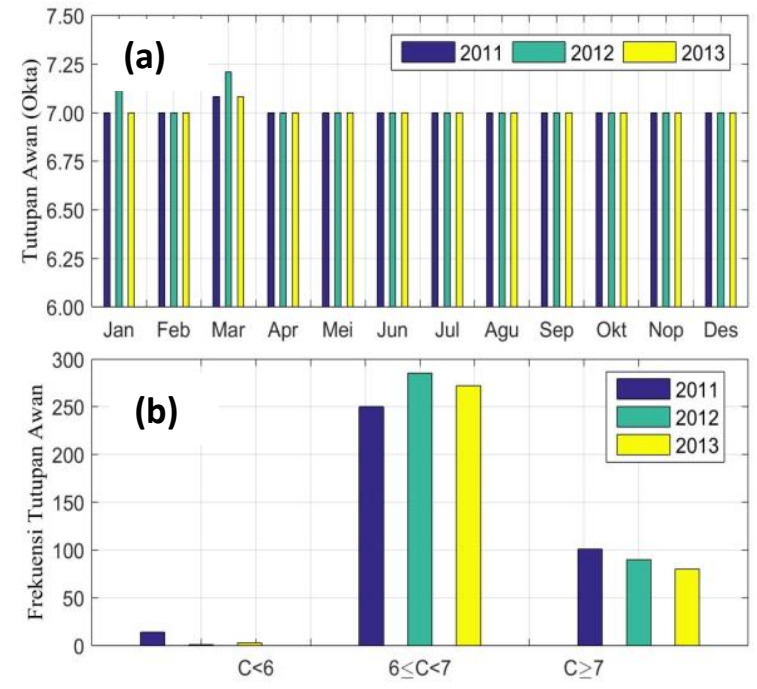

Gambar 3. Data tutupan awan (Okta) untuk 2011, 2012 dan 2013

Gambar 3(b) menunjukkan bahwa tren tutupan awan harian cenderung mengikuti distribusi normal di mana mayoritas tutupan awan adalah antara 6 dan 7. Ini muncul selama musim panas, di mana setiap tahun pada bulan Juni dan Juli 2011 hingga 2013 sering mengalami penutupan awan tinggi (5 okta) dibandingkan dengan bulan-bulan lainnya dalam tiga tahun terakhir. Namun, tutupan awan di tingkat ini untuk menghasilkan ribut badai adalah kurang signifikan. Angin dan transfer panas akan menggeser dan menyerap pembentukan badai. Badai akan terbentuk ketika awan kumulonimbus dikembangkan di langit di mana hujan lebat, salju atau hujan es, dan petir akan terjadi. Dengan kata lain, angin dingin sering memicu terjadinya badai.

\section{Ribut Badai}

Gambar 4 menunjukkan frekuensi badai di sekitan daerah Tawau untuk periode 2011-2013. Selama musim panas di 
tahun 2012 dan 2013, telah terjadi badai pada bulan Juni dan Juli, masing-masing dengan 11 dan 8 ribut badai. Juli dan Desember menunjukkan frekuensi terendah terjadinya ribut badai dibandingkan bulan lainnya karena musim kering terjadi di wilayah ini.

Selama Juni dan Juli 2011, terjadi 10 dan 12 ribut badai, dibandingkan dengan rata-rata 8 dan 11 masing-masing pada tahun 2012 dan 2013. Perubahan musim di Asia selama musim panas di bulan Agustus 2012 adalah salah satu kondisi yang mempengaruhi cuaca di kawasan Asia Tenggara (Loo et al., 2015).

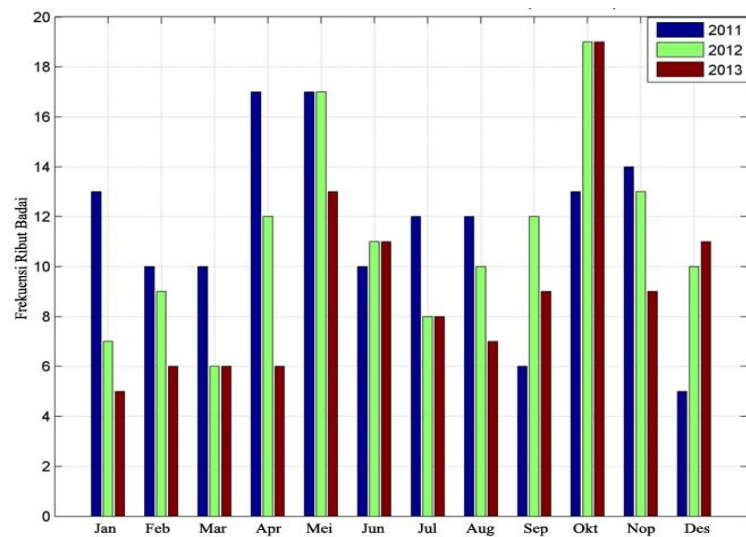

Gambar 4. Frekuensi terjadinya ribut badai di sekitar Tawau pada 2011, 2012, dan 2013

Frekuensi ribut badai dapat dikaitkan dengan data awan di mana selama musim panas di bulan Agustus 2011 dan 2012, frekuensi badai meningkat ketika awan berkurang. Ini kontras dengan temuan Panneerselvam et al. (2007) di mana dalam analisisnya menemukan bahwa kejadian badai petir berkorelasi positif dengan data awan.

Satu yang dapat kita pelajari dari perbedaan ini adalah lokasi pengukuran atau karakteristik atmosfer di masingmasing daerah adalah tidak sama. Pola cuaca yang berbeda dapat mempengaruhi daratan/lautan dengan cara yang berbeda. Dengan kata lain, berbagai wilayah dengan komposisi atmosfer yang berbeda akan merespon dengan perbedaan pantulan radiasi matahari yaitu mekanisme dalam transfer energinya.

\section{Data Meteorologi Permukaan}

Tekanan permukaan, suhu, dan kelembaban relatif untuk daerah Tawau diplot seperti pada Gambar 5 untuk mengidentifikasi terjadinya badai. Selama musim kemarau di bulan Juli 2011, 2012 dan 2013, baik suhu maupun tekanan diperoleh bacaan tinggi sedangkan kelembaban adalah rendah.

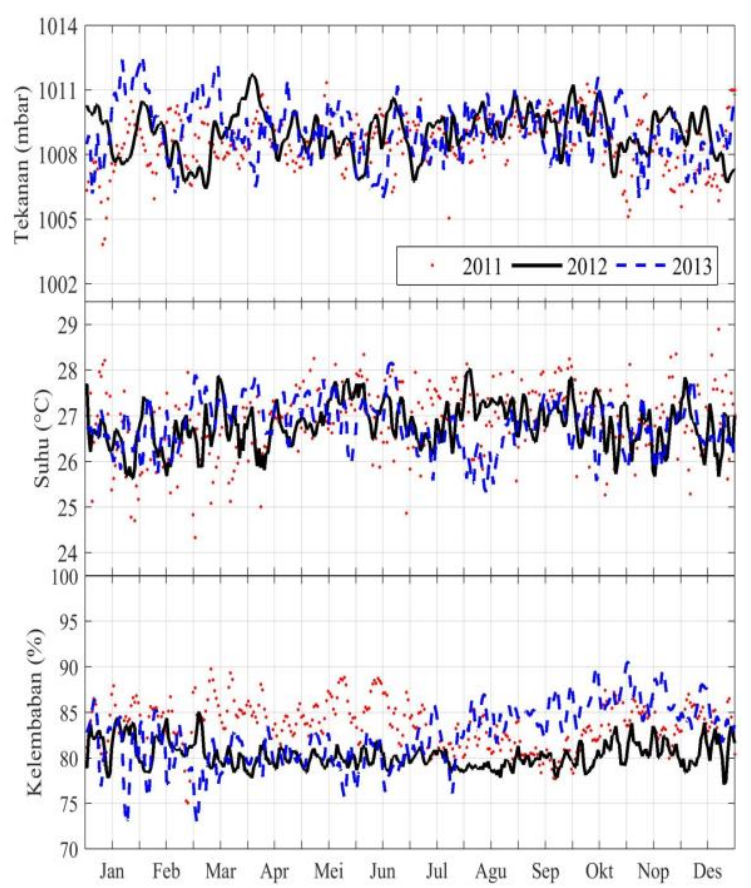

Gambar 5. Variasi tekanan permukaan, suhu, dan kelembaban relatif untuk periode 2011, 2012 dan 2013

Berbeda dengan awal Agustus 2013, bacaan suhu adalah minimum dibandingkan suhu bulan lain pada tahun 2011, 2012, dan 2013. Pada keadaan ini, nilai kelembaban relatif dan tekanan permukaan di udara adalah sangat tinggi. Keadaan inilah memunculkan peluang untuk terjadinya badai adalah tinggi. Temuan ini sejalan dengan Suparta et al. (2011) di mana selama awal peningkatan suhu permukaan dan mulai menurunnya kelembaban relatif, akan menyebabkan peningkatan uap air dan peluang terjadinya ribut badai adalah tinggi. Dari gambar tersebut, bulan OktoberNovember terlihat bulan yang membawa 
cuaca ekstrim yang signifikan ke wilayah ini di mana tekanan menurun diikuti oleh peningkatan kelembaban di atmosfer. Wilayah terdampak yang dimaksud adalah Laut Sulawesi dimana imbas dari kejadian ini mempengaruhi aktivitas nelayan di laut dalam.

\section{PWV}

Parameter meteorologi terakhir yang dilihat untuk mendeteksi pengaruhnya terhadap kemunculan badai adalah PWV. Gambar 6 menunjukkan PWV diambil dari Radiosonde untuk periode 2011-2013. Ada peningkatan PWV selama akhir Mei hingga awal Juni 2011. Jika dikaitkan dengan Gambar 4, badai tinggi selama waktu ini sering terjadi. Frekuensi ribut badai yang tinggi dapat dikaitkan dengan kejadian musim peralihan dimana kecenderungannya sama seperti yang diperoleh pada bulan Oktober-November di setiap tahun. Selama tahun 2012, PWV dengan data rata-rata harian diamati lebih tinggi di bulan Maret, awal Juni, Juli, September dan Oktober. Namun, pola tahunan PWV seperti pada Gambar 6(a) masih sulit diidentifikasi dan oleh karena itu, rata-rata bulanan diproses seperti pada Gambar 6(b).

Gambar 6(b) ini dengan jelas menunjukkan bahwa uap air meningkat selama musim peralihan (intermonsun). Ini berarti bahwa PWV juga merupakan sebuah indikator yang presisi untuk menggantikan data ribut badai jika datanya tidak tersedia, dimana bulan April-Mei dan Oktober menunjukkan posisi uap air yang tinggi. Uap air yang tinggi berpotensi menghasilkan ribut cuaca. Sementara uap air akan menurun selama musim hujan karena suhu relatif tinggi dan kelembaban relatif rendah. Untuk wilayah Malaysia, uap air dalam istilah PWV ini lebih dipengaruhi oleh kelembaban relatif daripada tekanan permukaan (Suparta and Alhasa, 2016). Ketika kelembaban relatif tinggi dan tekanan rendah, ini memberikan sinyal bahwa ada kemungkinan terjadi badai (atau frekuensi terjadinya badai). Secara implisit ini berarti bahwa badai tidak akan selalu terjadi jika PWV menurun atau meningkat. Ada faktor eksternal lain yang mempengaruhi pembentukan badai ini, terutama badai cuaca ketika roket sudah berada di luar angkasa atau menuju orbit.
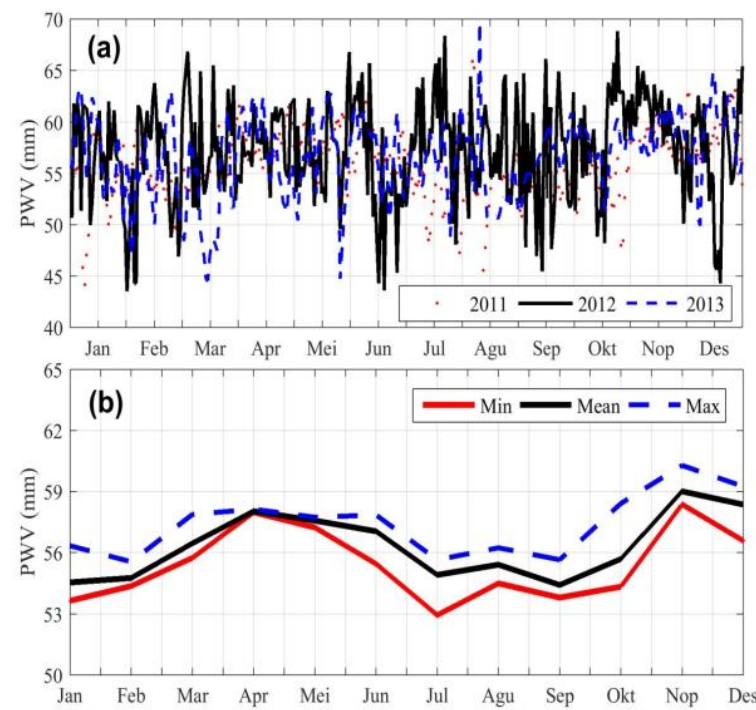

Gambar 6. Variasi PWV di stasiun Tawau untuk tahun 2011, 2012 dan 2013 pada (a) setiap hari dan (b) rata-rata bulanan

\section{KESIMPULAN}

Karakterisasi data meteorologi permukaan telah dilakukan untuk daerah Tawau yang berdekatan dengan wilayah kemaritiman Indonesia yaitu Selat Makassar. Parameter meteorologi ditemukan berkorelasi tinggi dengan badai cuaca menjelang musim kemarau. Pada bulan Juli setiap tahun ditemukan kondisi cuaca dengan suhu tinggi rata-rata $28^{\circ} \mathrm{C}$, tekanan rendah 1006 mbar dan kelembaban relatif di bawah $80 \%$ serta PWV serendah $45 \mathrm{~mm}$. Faktor cuaca di musim ini dilihat berkontribusi besar terhadap pengurangan terjadinya ribut badai. Selama musim peralihan, Tawau dan sekitarnya ditandai sebagai musim kering atau musim panas di mana tekanan rendah dan suhu tinggi di udara akan menurunkan kelembaban relatif dan berkontribusi untuk menurunkan kadar uap air di udara. Dengan kata lain, ribut badai di sekitar daerah ini hingga ke radius $500 \mathrm{~km}$ dari Tawau lebih dipengaruhi oleh kelembaban relatif dan uap air atmosfer. 
Berdasarkan hasil penelitian di atas, kecepatan angin selama musim peralihan terjadi di kelas dua (1-4 knot). Angin kelas tiga (berbahaya) umumnya dari arah Selatan (Selat Makassar). Kesimpulannya, kondisi cuaca selama musim permulaan kemarau (Juni, Juli, Agustus - JJA) dengan rendahnya aktivitas ribut badai adalah sesuai untuk aktivitas kedirgantaraan. Sebaliknya di musim peralihan (Mei dan Oktober), aktivitas peluruncuran roket perlu kewaspadaan. Dengan penemuan awal ini, sebuah kerangka model badai cuaca dengan menggunakan pendekatan Kepakaran Manusia dalam Sistem Inferensi NeuroFuzzy Buatan (Artificial Neuro-Fuzzy Interference System Human Expert - ANFIS $H E)$ siap dibangun untuk penelitian selanjutnya.

\section{DAFTAR PUSTAKA}

1. Islam M.R., Saidur R., Rahim N.A., Assessment of wind energy potentiality at Kudat and Labuan, Malaysia using Weibull distribution function, Energy, Volume 3, issue 2, pp. 985-992, 2011.

2. Loo Y.Y., Billa L., Singh A., Effect of climate change on seasonal monsoon in Asia and its impact on the variability of monsoon rainfall in Southeast Asia, Geoscience Frontiers, Volume 6, Issue 6, pp. 817-823, 2011.

3. Morris C.J.G., Simmonds I., Plummer N., Quantification of the Influences of Wind and Cloud on the Nocturnal Urban Heat Island of a Large City, Journal of Applied Meteorology and Climatology, Volume 40, Issue 2, pp.169-182, 2001.

4. Panneerselvam C., Nair K.U., Selvaraj C., Jeeva K., Anil Kumar C.P., Gurubaran S., Diurnal variation of atmospheric Maxwell current over the low-latitude continental station, Tirunelveli, India $\left(8.7^{\circ} \mathrm{N}, 77.8^{\circ} \mathrm{E}\right)$, Earth, Planets and Space, Volume 59, Issue 5, pp. 429-435, 2007.

5. Pielke R.A., Influence of the spatial distribution of vegetation and soils on the prediction of cumulus convective rainfall, Reviews of Geophysics, Volume 39, Issue 2, pp. 151-177, 2001.

6. Suparta W., Adnan J., Ali M.A.M., Monitoring the association between lightning activities during the 2009 winter monsoon over Bangi Malaysia, 2011 International Conference on Environment Science and Engineering, Volume 8, pp. 101-106, 2011, (Online), (http://www.ipcbee.com/vol8/23S063.pdf, diakses 6 Juni 2018).

7. Suparta W., Adnan J., Ali M.A.M., Nowcasting the lightning activity in Peninsular Malaysia using the GPS PWV during the 2009 inter-monsoons, Annals of Geophysics, Voume 57, Issue 2, A0127, 2014, doi: https://doi.org/10.4401/ag-6373.

8. Suparta W., Putro W.S., Singh M.S.J., Asillam M.F., Characterization of GPS and Meteorological Parameters for Mesoscale Convective Systems Model over Tawau, Malaysia, Advanced Science Letters, Volume 21, 2015, doi:10.1166/asl.2015.5862.

9. Suparta W., Alhasa K.M. Modeling of tropospheric delays using ANFIS. Netherland: Springer International, 2016.

10. WRPLOT View ${ }^{\mathrm{TM}}$ : Wind rose plots for meteorological data, Release Notes, Lakes Environmental Software, 2011, (Online), (http://www.weblakes.com, diakses 1 Juni 2018). 